\title{
Comment on the Paper Entitled 'Haemostasis and Safety Measures before Lumbar Puncture at the Haematology Ward: The Danish Routines'
}

\author{
Laxmaiah Manchikanti ${ }^{a, b}$ Joshua A. Hirsch ${ }^{c-g}$ \\ a Pain Management Center of Paducah, Paducah, Ky., and ${ }^{\mathrm{b}}$ Anesthesiology and Perioperative Medicine, University of \\ Louisville, Louisville, Ky., and ${ }^{\mathrm{C} I n t e r v e n t i o n a l ~ C a r e, ~}{ }^{\mathrm{d}}$ Minimally Invasive Spine Surgery, ${ }^{\mathrm{e}}$ Interventional Radiology and \\ ${ }^{f}$ Endovascular Neurosurgery and Neuroendovascular Program, Massachusetts General Hospital, and ${ }^{g}$ Harvard \\ Medical School, Boston, Mass., USA
}

In this issue of Acta Haematologica, Møller et al. [1] assess the role of hemostasis and safety measures before lumbar puncture in hematology wards in Denmark. The results are not surprising. In an online survey, questions pertaining to the precautions of hemostasis and the application of fundoscopy were sent by e-mail to 12 hematology wards in Denmark, of which 11 participated. The results were highly variable, with $64 \%$ of the participating units establishing an international normalized rate limit of 1.5 , and the remaining units establishing a limit between 1.0 and 2.5. Surprisingly, 36\% of the departments utilized fundoscopy routinely. Platelet counts were also utilized in some units. More importantly, $45 \%$ reported no cessation of antiplatelet drug therapy. Consequently, the authors called for national guidelines to establish an evidence-based approach to handle patients at risk of bleeding when lumbar puncture or another invasive procedure is indicated.

Cardiovascular and cerebrovascular diseases are among the leading causes of significant impairment of physical and psychological health and performance of social responsibilities, including work and family life. These diseases are leading causes of morbidity and mortality $[2$, 3]. Antithrombotic therapy has been established to limit the present and future burden of cardiovascular and cere- (c) 2014 S. Karger AG, Base

0001-5792/14/1331-0106\$39.50/0 brovascular disorders $[2,4]$. It is no wonder that a significant proportion of patients with cardiovascular, cerebrovascular, or peripheral vascular disease who receive antithrombotic therapy also undergo surgical interventions and other interventional techniques, including lumbar punctures.

The risks of withdrawing antiplatelet therapy include cardiovascular, cerebrovascular, and peripheral vascular thrombosis which may result in ominous consequences, including stroke and death [4]. In addition, ceasing antiplatelet therapy may result in either hypercoagulability with thrombosis or bleeding complications. By the same token, studies assessing the risk of maintaining antiplatelet therapy have shown an increased surgical blood loss of $2.5-20 \%$ with aspirin and 30-50\% with aspirin and clopidogrel [2]. In addition, while there has been no increase in surgical mortality due to increased bleeding except during intracranial surgery, increased transfusions and mortality linked to massive surgical blood loss of less than $3 \%$ have been reported $[2,5]$. Overall, however, the risks of withdrawing antiplatelet therapy are substantial due to a possible rebound effect resulting in increased platelet adhesiveness and hypercoagulability.

There are also multiple reports of bleeding risk associated with continuing antiplatelet therapy [2].The general
KARGER 125\%

E-Mail karger@karger.com

www.karger.com/aha
Laxmaiah Manchikanti, MD

Pain Management Center of Paducah

2831 Lone Oak Road

Paducah, KY 42003 (USA)

E-Maildrlm@thepainmd.com 
trend has been to continue antiplatelet therapy prior to ophthalmologic procedures as well as vascular surgery and interventional techniques, including many spinal interventional techniques [2]. Multiple guidelines have been issued in reference to perioperative bleeding risks in patients on antiplatelet therapy undergoing interventional techniques, which are similar to lumbar puncture and surgical interventions $[2,6]$. This guidance incorporates American Society of Regional Anesthesia (ASRA) guidelines, American Society of Interventional Pain Physicians (ASIPP) guidelines, International Spine Intervention Society (ISIS) guidelines, Nordic guidelines, European guidelines, and Belgian guidelines. Except for the Nordic guidelines, all of them agree that NSAIDs may be continued. In reference to aspirin, all guidelines agree that there is no need to stop low-dose aspirin of $81 \mathrm{mg}$, except the Nordic guidelines, which advise to stop them for $12 \mathrm{~h}$. However, when aspirin is given in high doses, the advice is to stop them for 3-7 days, except for the European guidelines, which advise that it is not necessary to stop them. In reference to antiplatelet agents, multiple guidelines are also highly variable. There is unanimous opinion that dipyridamole may be continued along with cilostazol and the combination of dipyridamole and aspirin. However, there are differences of opinion regarding clopido- grel, prasugrel, and ticlopidine; they may be stopped or continued depending on the individual status of the patient. All guidelines agree that if clopidogrel, prasugrel, and ticlopidine are stopped, they should be stopped for 7-10 days.

The unfortunate reality is that none of these guidelines are based on appropriate or significant evidence. Many of the guidelines are related to regional anesthesia, thus they may be applied to lumbar punctures. Epidural hematomas have been reported to occur in 1 in 150,000 of all epidurals performed. Epidural hematomas in the cervical and thoracic spine are reported to be higher than in the lumbar spine. Subarachnoid bleeding or epidural hematoma is a serious risk influenced by needle size, technical expertise, and the number of puncture attempts.

In conclusion, we applaud the authors' call for studies to establish an evidence-based approach to handle patients at risk of bleeding when lumbar puncture or another invasive procedure is indicated.

\section{Disclosure Statement}

No conflicts of interest declared.

\section{References}

1 Møller A, Bjerrum OW, Afshari A: Haemostasis and safety measures before lumbar puncture at the haematology ward: the Danish routines. Acta Haematol 2015;133:106107.

$>2$ Manchikanti L, Falco FJ, Benyamin RM, Caraway DL, Kaye AD, Helm S 2nd, Wargo BW, Hansen H, Parr AT, Singh V, Swicegood JR, Smith HS, Schultz DM, Malla Y, Hirsch JA: Assessment of bleeding risk of interventional techniques: a best evidence synthesis of practice patterns and perioperative management of anticoagulant and antithrombotic therapy. Pain Physician 2013;16:SE261-SE318.

$>3$ Schiller JS, Lucas JW, Ward BW, Peregoy JA: Summary health statistics for U.S. adults: National Health Interview Survey, 2010. Vital Health Stat 2012;252:1-207.
4 Biondi-Zoccai GG, Lotrionte M, Agostoni P, Abbate A, Fusaro M, Burzotta F, Testa L, Sheiban I, Sangiorgi G: A systematic review and meta-analysis on the hazards of discontinuing or not adhering to aspirin among 50,279 patients at risk for coronary artery disease. Eur Heart J 2006;27:2667-2674.

5 Manchikanti L, Malla Y, Wargo BW, Cash KA, McManus CD, Damron KS, Jackson SD, Pampati V, Fellows B: A prospective evaluation of bleeding risk of interventional techniques in chronic pain. Pain Physician 2011; 14:317-329.
Manchikanti L, Abdi S, Atluri S, Benyamin RM, Boswell MV, Buenaventura RM, Bryce DA, Burks PA, Caraway DL, Calodney AK, Cash KA, Christo PJ, Cohen SP, Colson J, Conn A, Cordner HJ, Coubarous S, Datta S, Deer TR, Diwan SA, Falco FJ, Fellows B, Geffert SC, Grider JS, Gupta S, Hameed H, Hameed M, Hansen H, Helm II S, Janata JW, Justiz R, Kaye AD, Lee M, Manchikanti KN, McManus CD, Onyewu O, Parr AT, Patel VB, Racz GB, Sehgal N, Sharma M, Simopoulos TT, Singh V, Smith HS, Snook LT, Swicegood J, Vallejo R, Ward SP, Wargo BW, Zhu J, Hirsch JA: An update of comprehensive evidence-based guidelines for interventional techniques of chronic spinal pain. Part II: guidance and recommendations. Pain Physician 2013;16:S49-S283. 